\title{
Study of adsorption isotherms of green coconut pulp
}

\author{
Estudo das isotermas de adsorção da polpa de coco verde
}

\author{
Fábia Carolina Gonçalves LAVOYER ${ }^{1 \star}$, Ana Lúcia GABAS², Wanderley Pereira OLIVEIRA ${ }^{3}$, Javier TELIS-ROMERO ${ }^{1}$
}

\begin{abstract}
Brazil is considered one of the largest producers and consumers of tropical fruits. Green coconut (Cocos nucifera L.) stands out not only for its production and consumption, but also for the high amount of waste produced by coconut water industry and in natura consumption. Therefore, there is a need for utilization of this by-product. This study aims to study the adsorption isotherms of green coconut pulp and determine its isosteric heat of sorption. The adsorption isotherms at temperatures of $30,40,50,60$, and $70{ }^{\circ} \mathrm{C}$ were analyzed, and they exhibit type III behavior, typical of sugar rich foods. The experimental results of equilibrium moisture content were correlated by models present in the literature. The Guggenheim, Anderson and De Boer (GAB) model proved particularly good overall agreement with the experimental data. The heat of sorption determined from the adsorption isotherms increased with the decrease in moisture content. The heat of sorption is considered as indicative of intermolecular attractive forces between the sorption sites and water vapor, which is an important factor to predict the shelf life of dried products.

Keywords: agro-industrial by-products; green coconut; thermodynamic properties; sorption isotherms.
\end{abstract}

\section{Resumo}

O Brasil é considerado um dos maiores produtores e consumidores de frutas tropicais. O coco verde (Cocos nucifera L.) se destaca tanto em termos de produção e consumo quanto em quantidade de resíduos gerada por indústrias de água de coco e pelo consumo in natura. Portanto, existe uma necessidade de aproveitamento deste subproduto. Este trabalho teve por objetivo estudar as isotermas de adsorção da polpa de coco verde e determinação do calor isostérico de sorção. As isotermas de adsorção para as temperaturas de 30, 40 , 50, 60 e $70{ }^{\circ} \mathrm{C}$ foram analisadas e evidenciaram curvas do tipo III, típicas de alimentos ricos em açúcares. Os dados experimentais de umidade de equilíbrio foram correlacionados por modelos da literatura. O modelo de GAB apresentou melhor concordância com os dados experimentais, entre os modelos avaliados. O calor isostérico de sorção é considerado um indicativo de forças atrativas intermoleculares entre os sítios de sorção de vapor de água, consequentemente, um importante fator para predizer a vida de prateleira de produtos desidratados.

Palavras-chave: subprodutos agroindustriais; coco verde; propriedades termodinâmicas; isotermas de sorção.

\section{Introduction}

Brazil is third largest coconut producer in the world - it produces over 1.5 million tons of the fruit every year (FOOD..., 2009). The Northeastern region stands out for its large areas of cultivated land and quantity of fruits produced, and it is responsible for distributing green coconut, brown coconut, and by-products throughout Brazil (SILVA, 2006).

The green coconut belongs to the species Cocos nucifera Linn., subfamily Cocosidae, family Palmae. The species comprises some varieties, e.g. Giant (Typica) and Dwarf (Nana) (ARAGÃO et al., 2002). The Dwarf-green coconut, introduced in Brazil in 1925, is small and each tree yields 120 to 150 fruits per year. The coconut tree can reach the age of forty years (ROSA; ABREU, 2000).

Most of Brazil's coconut production focuses on the growing of brown coconut (nearly $85 \%$ of the whole production), and a minor part corresponds to green coconut for water extraction. Both types are used for domestic consumption and industry
(SENHORAS, 2003). The industrialization of coconut water, traditionally consumed fresh, directly from the fruit favors the consumption far from its production areas since it reduces the volume and weight to be transported. Accordingly, it also reduces coconut's transport costs and shelf life (ROSA; ABREU, 2000).

Nowadays, coconut water has become popular, which has contributed to the growth of coconut production, responsible for nearly 6.7 million tons of coconut bark every year (MOURA et al., 2008; MACHADO; DAMM; FORNARI, 2009). Coconut's waste can be fully used. From its external layer (exocarp) and the fibrous mesocarp, it is possible to make doormats, brushes, heavy fabrics, household objects, etc. The green coconut pulp (internal layer) is high in fiber and vitamins, mineral salts, potassium, sodium, phosphorus, chlorine, and vitamin C. Using the green coconut pulp is, particularly, a way of reducing losses and, hence, avoiding waste (MEDINA, 1980).

Received 11/4/2012

Accepted 22/10/2012 (005660)

1 Departamento de Engenharia e Tecnologia de Alimentos, Instituto de Biociências, Letras e Ciências Exatas, Universidade Estadual Paulista - UNESP, CEP 15054-000,

São José do Rio Preto, SP, Brasil, e-mail: fabiacarolinagl@hotmail.com

2 Universidade de São Paulo - USP, Pirassununga, SP, Brasil

${ }^{3}$ Universidade de São Paulo - USP, Ribeirão Preto, SP, Brasil

${ }^{*}$ Corresponding author 
At the adequate maturation stage, green coconuts to be reused have little meat, and thus its use not economically viable. Nonetheless, when there is a significant amount due to the large volume processed, the industry can use the pulp in natura, especially in the production of candies, ice cream, yoghurt, beverages, etc (ROSA; ABREU, 2000).

According to the Decree No. 7404 of 23 December 2010, which regulates Solid Waste Law No. 12305, it is mandatory that every city recycles its own waste and promotes research and development of recycling activities, as provided in Article No. 4 Paragraph VI (BRASIL, 2010).

Accordingly, the procedure of drying green coconut waste products enables them to be used by the food, chemical and pharmaceutical industry. Moreover, it enables the producers to process these waste products creating employment opportunities while helping reduce the amount of waste generated.

Coconut's edible parts (white pulp and water) can be consumed inside the fruit as well as processed by industry when the fruit is still green. The green coconut pulp is jelly-like and can be consumed in natura after the water has been extracted. In cases of water industrialization, the pulp can be used for the production of homemade candies and to feed animals or even as a protective mantle of soil to grow coconut trees.

Hygroscopic properties information is of great importance to develop the drying process and determine the storage conditions of the green coconut pulp. The drying time and storage conditions of this fruit can be determined by assessing its thermodynamic properties such as moisture adsorptiondesorption isotherms, and isosteric heat of sorption. Studies conducted by Gabas, Menegalli and Telis-Romero (1999) on grapes, Gabas, Menegalli and Telis-Romero (2000) on persimmons, and Telis et al. (2000) on plums, point out the importance of thermodynamic properties in the prediction of the drying time of fruits and determine the final product shelf life.

Water sorption isotherm is a balance relationship between the water-holding capacity of solid food and the water activity $\left(a_{\mathrm{w}}\right)$ or relative humidity $(\mathrm{RH} \%)$ of the storage environment at constant temperature plays a key role in dehydrated food preservation studies (LABUZA, 1968).

Water has a very important role in food stability due to its contribution to chemical, physical, and microbiological reactions. The water available in a certain type of food, capable of causing these reactions to occur, can be easily removed by drying procedures and is closely related to water activity $\left(a_{\mathrm{w}}\right)$. This parameter is defined as the ratio of the water vapor pressure of the food $(P)$ to the water vapor pressure of pure water $\left(P_{0}\right)$ under the same temperature and pressure (Equation 1) (BARBOSA-CÁNOVAS et al., 2007).

$a_{w}=\frac{P}{P_{0}}=\frac{R H}{100}$

where: $\mathrm{RH}$ is relative humidity (\%)
According to Rizvi (1995), the ratio shown in Equation 1 is a critical parameter for analyzing the phenomenon of mass and heat transfer, as well as the thermodynamic properties which occur during dehydration because it determines the final stage at which the food can be dehydrated. This final stage depends on several factors including the food chemical composition, physicochemical state of the ingredients, and structural properties. It is also important for packaging and storage studies since it enables to select the properties of the materials that will be used in the packages and appropriate storage conditions (RIZVI, 1995).

If humidity has been absorbed, isotherms are called adsorption isotherms, otherwise they are called desorption isotherms (STRUMILLO; KUDRA, 1986). Brunauer et al. (1940) classified sorption isotherms into five general groups based upon the Van der Waal adsorption of non-polar gases adsorbing on nonporous solid substrates. Type I isotherms occur when water is strongly attracted to the product; type II, when water is scarcely attracted to the product and frequently present in small capillaries; in type III, the water content of the product is in large capillaries and can be considered as free water; as for the types IV and V, the maximum adsorption occurs at a pressure lower than the vapor pressure of the gas (BARBOSACÁNOVAS et al., 2007).

In solids, the internal pore size limits water adsorption. In most foods, moisture sorption isotherms are often observed in sigmoidal shape and classified as type II. Foods that are rich in soluble compounds such as sugars usually behave as type III. This study aimed to obtain adsorption isotherms and determine the isosteric heat of sorption of green coconut pulp under different temperatures.

\subsection{Mathematical analysis}

The BET model (Brunauer, Emmett, and Teller) is one of the most widely used theoretical models to describe sorption isotherms of food because it ensures a good fit for a great variety of products with low water activity. The model is restrictively applicable within the 0.05 to $0.45 a_{\mathrm{w}}$ range (Equation 2) (RIZVI, 1986).

$X_{e q}=\frac{X_{m} C a_{w}}{\left(1-a_{w}\right)\left(1+(C-1) a_{w}\right)}$

where: $X_{\text {eq }}=$ equilibrium moisture content $(\%, \mathrm{db})$; $X_{\mathrm{m}}=$ monolayer moisture content $(\%, \mathrm{db}) ; C=$ BET constant related to the heat of sorption, expressed by the following Equation 3:

$C=k \exp \left(\frac{\Delta H_{B E T}}{R T}\right)$

where: $k=$ constant of equation; $R=$ universal gas constant $\left(\mathrm{kJ} \cdot \mathrm{mol}^{-1}\right) ; \Delta H_{\mathrm{BET}}=$ total heat of sorption of the model $\left(\mathrm{kJ} \cdot \mathrm{mol}^{-1}\right)$; $T=$ temperature $(\mathrm{K})$.

The GAB model (Guggenheim, Anderson, and Boer) has three parameters (Equation 4) and has been largely used in foods 
due to its application in a wide $a_{\mathrm{w}}$ range (0.1 to 0.9) (IGLESIAS; CHIRIFFI, 1995; LABUZA; KANANE; CHEN, 1985).

$X_{e q}=X_{m}\left[\frac{(C-1) K a_{w}}{\left(1+(C-1) K a_{w}\right)}+\frac{K a_{w}}{\left(1-K a_{w}\right)}\right]$

where: $\mathrm{C}=$ Guggenheim constant, expressed by:

$$
C=\operatorname{Kexp}\left(\frac{H_{m}-H_{n}}{R T}\right)
$$

where: $H_{\mathrm{m}}=$ total heat of sorption of the first layer (monolayer) $\left(\mathrm{kJ} \cdot \mathrm{mol}^{-1}\right) ; H_{\mathrm{n}}=$ total heat of sorption of the multilayers $(\mathrm{kJ}$. $\left.\mathrm{mol}^{-1}\right) ; K=$ constant of Equation 6:

$$
K=k_{0} \exp \left(\frac{\lambda-H_{n}}{R T}\right)
$$

where: $k_{0}=$ constant of equation; $\lambda=$ heat of condensation of pure water $\left(\mathrm{kJ}^{\mathrm{kgg}}{ }^{-1}\right)$.

One of the most widely used empirical models in food is the modified Halsey model. It considers that condensation occurs in the multilayer relatively far from the surface and assumes that the parameter magnitude characterizes the type of interaction between the vapor and the solid (Equation 7) (RIZVI, 1986).

$U_{e q}=\left(\frac{k}{\ln c / a_{w}}\right)^{1 / r}$

where: $k, c$, and $r$ are constants of the modified Halsey model (1948).

The isosteric heat of sorption $\left(q_{\mathrm{st}}\right)$ is a thermodynamic parameter which can be obtained by means of equilibrium moisture data. It expresses the amount of energy required to adsorb or desorb water from food. Its value is defined as the total heat of sorption $\left(Q_{\mathrm{st}}\right)$ minus the heat of vaporization of water at system temperature. Based upon thermodynamic principles, the isosteric heat of sorption can be determined by Equation 8, which arises from the Clausius-Clapeyron equation, used for pure water systems (AL-MUHTASEB; McMINN; MAGEE, 2004).

$q_{s t}=-R \frac{\partial\left(\ln a_{w}\right)}{\partial(1 / T)}=Q_{s t}-\lambda$

where: $Q_{\mathrm{st}}=$ total heat of sorption $\left(\mathrm{kJ} \cdot \mathrm{mol}^{-1}\right)$.

Two methods can be used to determine the isosteric heat of sorption: firstly, by taking a calorimetric measurement of the present heat directly; secondly, by applying the ClausiusClapeyron equation at different temperatures. The former method is not frequently used due to the difficulty of measuring small quantities of heat. Thus, it is more commonly used to calculate it from sorption isotherm data (AL-MUHTASEB; McMINN; MAGEE, 2004).
The knowledge of the dependence of the heat of sorption of water on moisture content can be used to estimate the energy needed in the drying procedure and provide important data on water behavior in food products (TSAMI; MARINOS-KOURIS; MAROULIS, 1990). Equation 9 shows the empirical exponential relationship proposed by Tsami, Marinos-Kouris and Maroulis (1990) between the heat of sorption and moisture content.

$q_{s t}=q_{0} \exp \left(-X_{e q} / X_{0}\right)$

where: $q_{0}=$ isosteric heat of sorption of the first water molecule $\left(\mathrm{kJ} \cdot \mathrm{mol}^{-1}\right) ; X_{0}=$ characteristic moisture content of the food product (\%).

\section{Materials and methods}

\subsection{Sample preparation}

The coconut pulp was obtained from green coconut acquired from the local market of São José do Rio Preto, SP, Brazil. The coconuts had a green coloration, a thin layer of pulp, and large quantity of water, characteristics that are similar to those of the product used by the coconut water industry. The water was removed, and the coconuts were split in half. Subsequently, the pulp was removed manually and processed using a regular blender for two minutes. The pulp was frozen and thawed before use.

\subsection{Adsorption isotherms}

The equilibrium moisture content was determined by the gravimetric static method (JOWITT et al., 1983), following procedures to obtain adsorption isotherms for temperatures of $30,40,50,60$, and $70{ }^{\circ} \mathrm{C}$. The green coconut pulp had been previously dried in vacuum oven for 48 hours. The experiments were conducted in triplicate and $1 \mathrm{~g}$-samples of the dried coconut pulp and ten saturated salt solutions with relative humidity ranging from 2 to $90 \%$ were used (Table 1 ).

Table 1. Activity of water of saturated salt solutions in relation to the

\begin{tabular}{|c|c|c|c|c|c|}
\hline \multicolumn{6}{|c|}{ Activity of water (\%) } \\
\hline \multicolumn{6}{|c|}{ Temperature $\left({ }^{\circ} \mathrm{C}\right)$} \\
\hline Salts & 30 & 40 & 50 & 60 & 70 \\
\hline $\mathrm{NaOH}$ & 0.069 & 0.066 & 0.059 & 0.045 & 0.02 \\
\hline $\mathrm{LiCl}$ & 0.112 & 0.111 & 0.11 & 0.11 & 0.11 \\
\hline $\mathrm{KC}_{2} \mathrm{H}_{3} \mathrm{O}_{2}$ & 0.223 & 0.206 & 0.189 & 0.175 & 0.162 \\
\hline $\mathrm{MgCl}_{2}$ & 0.324 & 0.319 & 0.314 & 0.307 & 0.294 \\
\hline $\mathrm{K}_{2} \mathrm{CO}_{3}$ & 0.439 & 0.432 & 0.432 & 0.432 & 0.432 \\
\hline $\mathrm{Mg}\left(\mathrm{NO}_{3}\right)_{2}$ & 0.526 & 0.506 & 0.489 & 0.473 & 0.458 \\
\hline $\mathrm{NaNO}_{2}$ & 0.635 & 0.615 & 0.599 & 0.59 & 0.587 \\
\hline $\mathrm{NaCl}$ & 0.756 & 0.753 & 0.746 & 0.74 & 0.739 \\
\hline $\mathrm{KCl}$ & 0.835 & 0.82 & 0.809 & 0.8 & 0.795 \\
\hline $\mathrm{BaCl}_{2}$ & 0.9 & 0.893 & 0.884 & 0.876 & 0.87 \\
\hline
\end{tabular}
temperature (LABUZA; KAANANE; CHEN, 1985; YOUNG, 1967). 
Samples of green coconut dehydrated pulps, whose initial mass was known, were placed in a plastic container on a tripod and inserted in hermetic containers with saturated salt solutions of the salts shown in Table 1. These containers were closed and kept in oven with controlled air circulation and temperature. Weekly quantifications of the sample masses were performed in analytical scales with accuracy $\pm 0.0001 \mathrm{~g}$, until they reached constant mass. After reaching balance, the equilibrium moisture was obtained in a vacuum oven at $60^{\circ} \mathrm{C}$ up to constant weight.

The results of the equilibrium moisture contents were plotted as a function of water activity. The experimental data were adjusted using the graphics software Origin 6.0 Professional with the mathematical models BET (Equation 2), GAB (Equation 4) - one of the most utilized models for food products - and the modified Halsey empirical model (Equation 7). From the adsorption isotherms data, the isosteric heat of sorption data were calculated using the Equation 8 for each temperature studied.

\section{Statistical analyses}

The best model to predict the equilibrium moisture content was selected considering the magnitude of the determination coefficient $\left(\mathrm{R}^{2}\right)$ and the relative deviation $(\mathrm{P})$. The best model was calculated using the software Origin 6.0 Professional, and the $P$ was calculated using Equation 10. For a good mathematical fit, P should be less than $10 \%$ and $\mathrm{R}^{2}$ close to unity.

$P=\frac{100}{n} \sum_{i=1}^{n}\left(\frac{|Y-\hat{Y}|}{Y}\right)$

where: P: the relative deviation (\%); n: number of experimental observations; $\mathrm{Y}=$ experimental value; $\hat{Y}=$ estimated value by the model.

\section{Results and discussion}

\subsection{Adsorption isotherms}

Firstly, the pulp composition was determined according to AOAC standards (ASSOCIATION..., 1990), and the results were: $48 \mathrm{~g}$ of water, $3.9 \mathrm{~g}$ of protein, $44.2 \mathrm{~g}$ of total lipids, $0.9 \mathrm{~g}$ of ash, $4.9 \mathrm{~g}$ of fiber, and $8.7 \mathrm{~g}$ of total sugars per $100 \mathrm{~g}$ of pulp.

The equilibrium moisture $\left(X_{\mathrm{eq}}\right)$ data as a function of water activity obtained at the temperatures of $30,40,50,60$, and $70{ }^{\circ} \mathrm{C}$ for green coconut dehydrated pulp are shown in Table 2 , in which each equilibrium moisture value $\left(X_{\text {eq }}\right)$ represents the average of the triplicate experiments performed. It can be seen that as the temperature rises, the equilibrium moisture decreases reaching the same value of water activity, which shows that the coconut pulp becomes less hygroscopic (IGLESIAS; CHIRIFE, 1995). However, for water activity higher than 0.8 , an inversion occurs in the expected behavior of equilibrium moisture between 60 and $70^{\circ} \mathrm{C}$. The same behaviors were observed by Telis et al. (2000) for persimmon bark and pulp, Yoshida (1996) for adsorption isotherms of moisture of lyophilized super sweet
Table 2. Data on equilibrium moisture obtained by adsorption isotherms at the temperatures $30,40,50,60$, and $70^{\circ} \mathrm{C}$.

\begin{tabular}{|c|c|c|c|c|c|}
\hline \multicolumn{6}{|c|}{ Temperature $\left({ }^{\circ} \mathrm{C}\right)$} \\
\hline \multicolumn{3}{|c|}{30} & \multicolumn{3}{|c|}{40} \\
\hline$a_{w}$ & \multicolumn{2}{|c|}{$X_{e q(g / g)}$} & $a_{w}$ & \multicolumn{2}{|r|}{$X_{e q(g / g)}$} \\
\hline 0.069 & \multicolumn{2}{|c|}{$0.012 \pm 0.001$} & 0.066 & \multicolumn{2}{|c|}{$0.008 \pm 0.000$} \\
\hline 0.112 & \multicolumn{2}{|c|}{$0.020 \pm 0.001$} & 0.111 & \multicolumn{2}{|c|}{$0.014 \pm 0.000$} \\
\hline 0.223 & \multicolumn{2}{|c|}{$0.042 \pm 0.001$} & 0.206 & \multicolumn{2}{|c|}{$0.033 \pm 0.001$} \\
\hline 0.324 & \multicolumn{2}{|c|}{$0.066 \pm 0.001$} & 0.319 & \multicolumn{2}{|c|}{$0.053 \pm 0.000$} \\
\hline 0.439 & \multicolumn{2}{|c|}{$0.102 \pm 0.001$} & 0.432 & \multicolumn{2}{|c|}{$0.085 \pm 0.000$} \\
\hline 0.526 & \multicolumn{2}{|c|}{$0.139 \pm 0.004$} & 0.506 & \multicolumn{2}{|c|}{$0.108 \pm 0.001$} \\
\hline 0.635 & \multicolumn{2}{|c|}{$0.204 \pm 0.002$} & 0.615 & \multicolumn{2}{|c|}{$0.180 \pm 0.001$} \\
\hline 0.756 & \multicolumn{2}{|c|}{$0.345 \pm 0.004$} & 0.753 & \multicolumn{2}{|c|}{$0.309 \pm 0.002$} \\
\hline 0.835 & \multicolumn{2}{|c|}{$0.524 \pm 0.013$} & 0.820 & \multicolumn{2}{|c|}{$0.425 \pm 0.003$} \\
\hline 0.900 & \multicolumn{2}{|c|}{$0.785 \pm 0.009$} & 0.893 & \multicolumn{2}{|c|}{$0.720 \pm 0.002$} \\
\hline \multicolumn{6}{|c|}{ Temperature $\left({ }^{\circ} \mathrm{C}\right)$} \\
\hline \multicolumn{2}{|r|}{50} & \multicolumn{2}{|c|}{60} & \multicolumn{2}{|r|}{70} \\
\hline$a_{w}$ & $\mathrm{X}_{\mathrm{eq}(\mathrm{g} / \mathrm{g})}$ & $a_{w}$ & $\mathrm{X}_{\mathrm{eq}(\mathrm{g} / \mathrm{g})}$ & $a_{w}$ & $\mathrm{X}_{\mathrm{eq}(\mathrm{g} / \mathrm{g})}$ \\
\hline 0.059 & $0.006 \pm 0.000$ & 0.045 & $0.004 \pm 0.000$ & 0.020 & $0.001 \pm 0.000$ \\
\hline 0.110 & $0.012 \pm 0.000$ & 0.110 & $0.010 \pm 0.001$ & 0.110 & $0.009 \pm 0.001$ \\
\hline 0.189 & $0.024 \pm 0.001$ & 0.175 & $0.017 \pm 0.001$ & 0.162 & $0.013 \pm 0.001$ \\
\hline 0.314 & $0.047 \pm 0.001$ & 0.307 & $0.035 \pm 0.001$ & 0.294 & $0.030 \pm 0.001$ \\
\hline 0.432 & $0.078 \pm 0.000$ & 0.432 & $0.068 \pm 0.000$ & 0.432 & $0.057 \pm 0.002$ \\
\hline 0.489 & $0.095 \pm 0.002$ & 0.473 & $0.080 \pm 0.001$ & 0.458 & $0.067 \pm 0.003$ \\
\hline 0.599 & $0.156 \pm 0.002$ & 0.590 & $0.134 \pm 0.002$ & 0.587 & $0.119 \pm 0.002$ \\
\hline 0.746 & $0.298 \pm 0.002$ & 0.740 & $0.267 \pm 0.001$ & 0.739 & $0.253 \pm 0.007$ \\
\hline 0.809 & $0.407 \pm 0.005$ & 0.800 & $0.374 \pm 0.003$ & 0.795 & $0.345 \pm 0.014$ \\
\hline 0.884 & $0.701 \pm 0.004$ & 0.876 & $0.591 \pm 0.017$ & 0.870 & $0.606 \pm 0.018$ \\
\hline
\end{tabular}

corn and by Park, Bin and Brod (2001) for dehydrated pear. These results may be related to the temperature influence on water molecules' mobility, as well as the dynamic equilibrium between vapor phase and adsorption (AL-MUHTASEB; McMINN; MAGEE, 2004). According to Rizvi (1995), food composition can cause equilibrium moisture to decrease by increasing temperature at a certain water activity value. The high sugar concentration in the coconut pulp may have been responsible for an inversion in the behavior of the isotherms at high levels of water activity.

Figure 1 shows the adjustment of the experimental data by the GAB model. The represented curves are considered type III isotherms, typical of foods high in soluble compounds such as coffee, apple, banana, pineapple, and sugar rich food, according to the classification of Brunauer et al. (1940).

From the adjustments, Table 3 was created with the model parameters, coefficient of determination $\left(R^{2}\right)$, and relative deviation $(P)$. Observing the adjustments of the models in Table 3, it can be seen that the $\mathrm{R}^{2}$ was higher than 0.99 in the three models. Comparing the GAB model with the BET model, it can be observed that the former has $\mathrm{R}^{2}$ closer to 1.0 and presents $\mathrm{P} \leq 5 \%$. According to Timmermann, Chirife and Iglesias (2001), the GAB and BET models are closely related since the GAB model is an extension of BET model. Nevertheless, the GAB model comprehends a large range of water activity, from 0.05 to 0.95 . 
Comparing the GAB and modified Halsey models, it can be seen that the GAB model is used for ranges of water activity from 0.05 and 0.95 and the modified Halsey is used for water activity ranging from 0.05 to 0.8 ; in addition, the GAB model parameters $\left(X_{\mathrm{m}}\right.$ and $\left.K\right)$ have physical meanings. Moreover, the GAB model fits the best to the experimental data, in comparison to the other two models analyzed; Silva, Mata and Duarte (2005) found very good adjustment of this model to adsorption isotherms of cajá powder.

The value of the monolayer moisture content $\left(X_{\mathrm{m}}\right)$ in the $\mathrm{GAB}$ model indicates the amount of water that is strongly adsorbed to specific sites at the food surface, and this is a value that must be reached in order to assure food stability. The analysis of these values (Table 3 ) shows they are independent of temperature. Some authors obtained similar results for different foods; they found that the monolayer moisture content

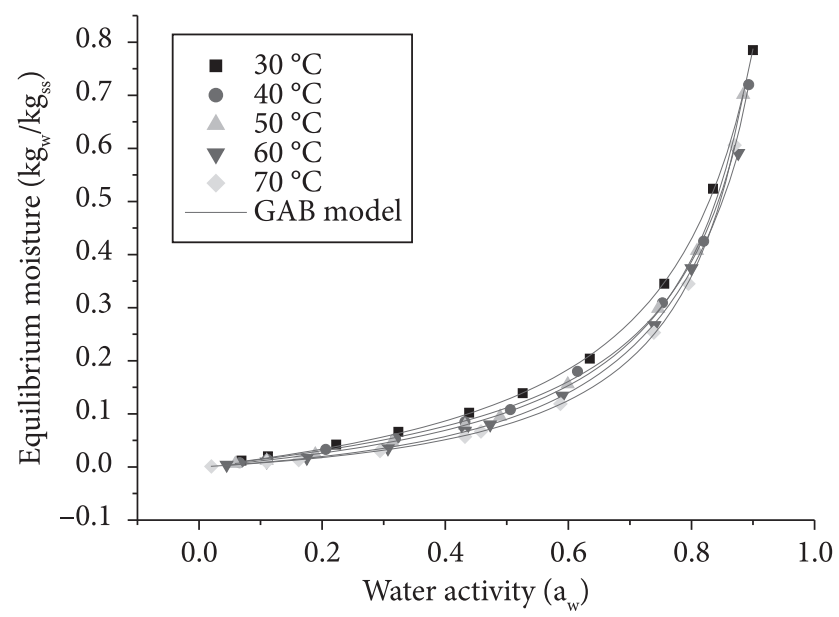

Figure 1. Adsorption isotherms with adjustment of GAB model.

Table 3. Parameters of the adjustments of models GAB, BET; and modified Halsey.

\begin{tabular}{lcccccc}
\hline \multirow{2}{*}{ Models } & \multirow{2}{*}{ Parameters } & \multicolumn{5}{c}{ Temperature $\left({ }^{\circ} \mathrm{C}\right)$} \\
\cline { 3 - 7 } & & 30 & 40 & 50 & 60 & 70 \\
\hline GAB & $\mathrm{C}$ & 1.0923 & 1.3032 & 0.9894 & 0.4273 & 0.6200 \\
& $\mathrm{~K}$ & 0.9470 & 0.9756 & 0.9806 & 0.9168 & 0.9877 \\
& $\mathrm{X}_{\mathrm{m}}$ & 0.1347 & 0.1031 & 0.1077 & 0.1832 & 0.1077 \\
& $\mathrm{P}$ & 4.7322 & 5.0663 & 2.9082 & 3.2914 & 5.5360 \\
& $\mathrm{R}^{2}$ & 0.9998 & 0.9995 & 0.9998 & 0.9999 & 0.9999 \\
& & & & & & \\
BET & $\mathrm{C}$ & 3.3931 & 2.2226 & 1.4419 & 1.3876 & 0.7637 \\
& $\mathrm{X}_{\mathrm{m}}$ & 0.0845 & 0.0825 & 0.1365 & 0.0829 & 0.0945 \\
& $\mathrm{P}$ & 17.1185 & 15.6674 & 66.2291 & 16.7064 & 8.0644 \\
& $\mathrm{R}^{2}$ & 0.9932 & 0.9980 & 0.9992 & 0.9965 & 0.9998 \\
modified & & & & & & \\
Halsey & $\mathrm{K}$ & 0.2131 & 0.1645 & 0.1786 & 0.2710 & 0.1841 \\
& $\mathrm{C}$ & 1.1551 & 1.0991 & 1.1073 & 1.2463 & 1.1124 \\
& $\mathrm{R}$ & 0.6512 & 0.6997 & 0.6453 & 0.5000 & 0.5749 \\
& $\mathrm{P}$ & 9.8807 & 21.3282 & 21.1496 & 11.9438 & 45.2482 \\
& $\mathrm{R}^{2}$ & 0.9998 & 0.99867 & 0.9992 & 0.9999 & 0.9997 \\
\hline
\end{tabular}

is constant and independent of temperature (GABAS et al., 2007). However, other authors found that $X_{\mathrm{m}}$ depends on the temperature (YOSHIDA, 1996; MISHRA; ORAIKUL; TEMELLI, 1996; ALEXANDRE, 2005; FERREIRA; PENA, 2003).

Strong adsorbent-adsorbate interactions, which are exothermic, are favored at lower temperatures causing an increase in $\mathrm{C}$ with decreasing temperature (Table 3). This is in accordance with Equation 5 that describes the temperature dependence of $\mathrm{C}$, which means that higher temperatures reduce the union energy of the first absorbed layer. The value of $\mathrm{K}$ provides a measure of interactions between the molecules in the multilayers with the adsorbent, and it tends to fall between the energy value of the molecules in the monolayer and that of liquid water. In the present study, the K parameter showed values from 0.91 to 0.99 and was not harshly affected by the temperature. However, this did not happen in the experiments of Alexandre (2005) on pitanga powder and Costa, Medeiros, and Mata (2003) on beet, carrot, and pumpkin powder, in which the $K$ parameter decreased as the temperature rose.

\subsection{Isosteric heat of sorption}

In order to calculate the isosteric heat of sorption, adsorption isotherms of coconut pulp were used, and the most appropriate model for these data was chosen - the GAB model.

Firstly, the isosters were calculated (Figure 2), whose values of equilibrium moisture were selected randomly within the experimental range found in the isotherms. For every value of activity of water, the Napier's logarithm was calculated and associated to the inverted values of the temperatures $\left(\mathrm{K}^{-1}\right)$. Dependence on temperature can be seen in Figure 2, in which the water activity rises as the temperature rises. A linear

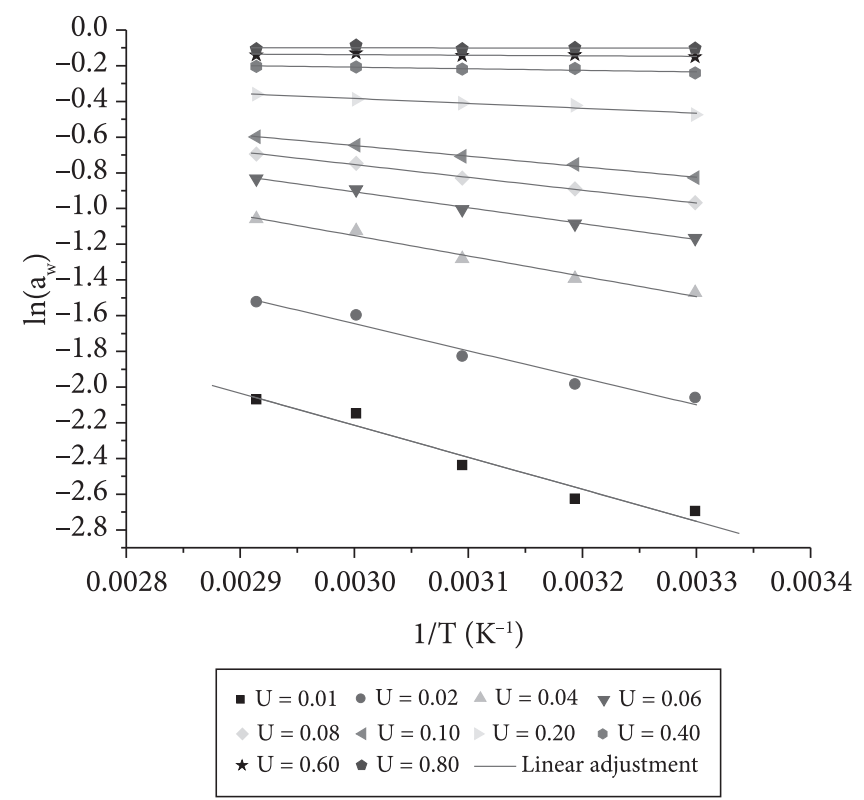

Figure 2. Isosters of green coconut pulp's adsorption isotherms. 


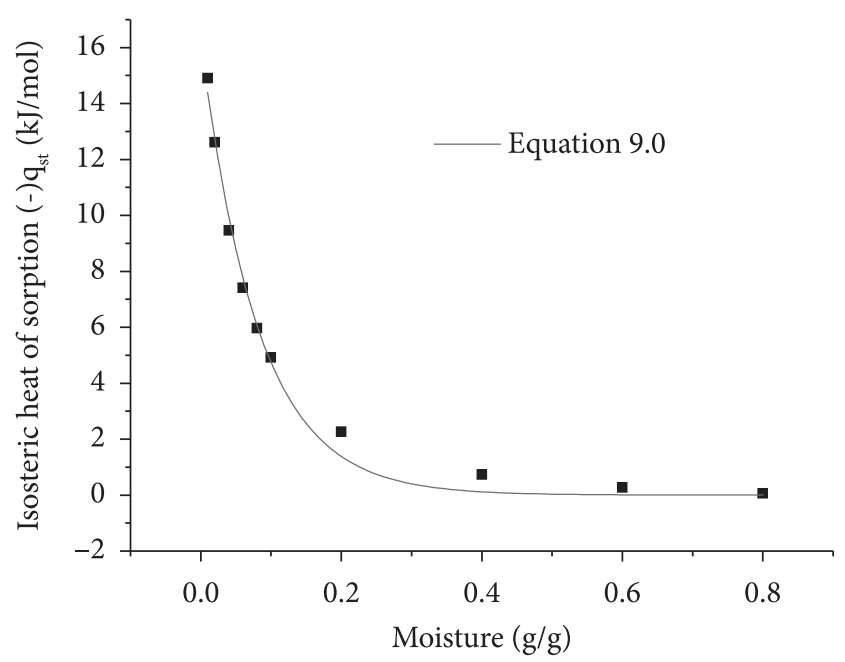

Figure 3. Isosteric heat of sorption for green coconut pulp.

adjustment was made where the angular coefficient was applied to calculate $q_{\text {st }}$ for every value of moisture using Equation 8 .

The relationship between the isosteric heat and the moisture content of the coconut pulp can be observed in Figure 3, which represents that the isosteric heat increases as the moisture content of the coconut pulp decreases. This behavior indicates the presence of strong interactions between water and pulp compounds, since isosteric heat represents the energy required to remove water from food. Similar results were obtained for pineapple (SIMAL et al., 2007), persimmon pulp and bark (TELIS et al., 2000), melon seeds (AVIARA; AJIBOLA, 2002), and corn grains (SAMAPUNDO et al., 2007).

The experimental data on isosteric heat of adsorption displayed in Figure 3 for green coconut pulp were adjusted by means of the empiric exponential equation (Equation 9), applied by Tsami, Marinos-Kouris and Maroulis (1990).

The $q_{0}$ value provides important information of interactions between food compounds and water, since this value simulates the energy required to remove the first water molecule of foods (BOQUET; CHIRIFE; IGLESIAS, 1978). The results $q_{0}=16.281 \mathrm{~kJ} / \mathrm{mol}$ and $X_{0}=0.08 \mathrm{~kg} / \mathrm{kg}(\mathrm{db})$ with $\mathrm{R}^{2}=0,998$ and $\mathrm{P}=0.5 \%$ are close to the results found by Tsami, Marinos-Kouris and Maroulis (1990) for dehydrated apricot $-q_{0}=10.3 \mathrm{~kJ} / \mathrm{mol}$ and $X_{0}=0.06 \mathrm{~kg} / \mathrm{kg}(\mathrm{db})$.

\section{Conclusion}

The curves of adsorption isotherms obtained for coconut pulp were type III, typical of food high in soluble compounds. The equilibrium moisture content increased with decreasing temperature at constant water activity. The model that fit best in the data of adsorption isotherms of coconut pulp was the GAB model, with a determination coefficient of approximately 1.0 and $\mathrm{P} \leq 5.0 \%$. The isosteric heat of sorption $\left(q_{\mathrm{st}}\right)$ increased as the moisture content of coconut pulp decreased, showing strong interactions between water and pulp compounds. It is important to note that, for moisture content less than $0.4 \mathrm{~kg} / \mathrm{kg}$ (dry basis), the negative increase in the isosteric heat of sorption should be considered in the simulation of energy requirements of the drying process. These data were adjusted by using Tsami model (TSAMI; MARINOS-KOURIS; MAROULIS, 1990) and resulted in a $q_{0}$ value of $16.28 \mathrm{~kJ} / \mathrm{mol}$ and $X_{0}$ value of $0.08 \mathrm{~kg} / \mathrm{kg}(\mathrm{db})$. The green coconut pulp, regarded as a by-product of coconut water industry, has not been the subject of much analysis, in spite of its big relevance for Brazil, which stands out as a major producer and consumer of coconut. Therefore, this paper can be helpful in future works concerning drying and storage of green coconut pulp.

\section{Acknowledgements}

The authors wish to thank the Bank of Brazil Foundation (FBB) for financial support (Procs. No 7.537).

\section{References}

ALEXANDRE, H. F. Secagem de polpa de pitanga e armazenamento do pó. 2005. Dissertação (Mestrado em Engenharia Agrícola)Universidade Federal de Campina Grande, Campina Grande, 2005.

AL-Muhtaseb, A. H.; McMinN, W. A. M.; MAgeE, T. R. A. Water sorption isotherm characteristic of food products: a review. Journal of Food Engineering, v. 62, p. 135-142, 2004. http://dx.doi. org/10.1016/S0260-8774(03)00202-4

ARAGÃO, W. M. et al. Variedades e híbridos do coqueiro. In: Aragão, W. M. et al. (Ed.). Coco pós-colheita. Brasília: EMBRAPA, 2002. p. 26-34. (Série Frutas do Brasil, n. 29; Informe Tecnológico).

ASSOCIATION OF OFFICIAL ANALYTICAL CHEMISTS - AOAC. Official Methods of Analysis. Washington: AOAC International, 1990.

AVIARA, N. A.; AJIBOLA, O. O. Thermodynamics of moisture sorption in melon seed and cassava. Journal of Food Engineering, v. 55, p. 107-113, 2002. http://dx.doi.org/10.1016/S0260-8774(02)00023-7

BARBOSA-CÁNOVAS, G. V. etal. Water activity in foods: fundamentals and applications. Ames: Blackwell Publishing Professional, 2007. PMid:17961286. http://dx.doi.org/10.1002/9780470376454

BOQUET, R.; CHIRIFE, J.; IGLESIAS, H. A. Equations for fitting water sorption isothermsfoods II: evaluation of various two-parameters models. International Journal of Food Science \& Technology, v. 13, n. 14, p. 319-327, 1978.

BRASIL. Ministério do Meio Ambiente, dos Recursos Hídricos e da Amazônia Legal. Decreto no 7.404, de 23 de dezembro de 2010. Regulamenta a Lei no 12.305, de 2 de agosto de 2010, que institui a Política Nacional de Resíduos Sólidos, cria o Comitê Interministerial da Política Nacional de Resíduos Sólidos e o Comitê Orientador para a Implantação dos Sistemas de Logística Reversa, e dá outras providências. Diário Oficial da República Federativa do Brasil, Brasília, DF, 23 dez. 2010. Edição extra. Disponível em: < http://www. planalto.gov.br/ccivil_03/_Ato2007-2010/2010/Decreto/D7404. htm>. Acesso em: 21 nov. 2011.

BRUNAUER, S. et al. On theory of the van der Waals adsorption of gases. Journal of the American Chemical Society, v. 62, p. 17231732, 1940. http://dx.doi.org/10.1021/ja01864a025

COSTA, J. M. C.; MEDEIROS, M. F. D; MATA, A. L. M. L. Isotermas de adsorção de pós de beterraba (Beta vulgaris L.), abóbora (Cucurbita moschata) e cenoura (Daucus carota) obtidos pelo processo de 
secagem em leito de jorro: estudo comparativo. Revista Ciência Agronômica, v. 34, n. 1, p. 5-9, 2003.

FERREIRA, C. D.; PENA, R. S. Comportamento higroscópico da farinha de pupunha (Bactris gasipaes). Ciência e Tecnologia de Alimentos, v. 23, n. 2, p. 251-255, 2003. http://dx.doi.org/10.1590/ S0101-20612003000200025

FOOD AND AGRICULTURE ORGANIZATION - FAO. Coconut production. FAO, 2009. Disponível em: <https://www.fao.org.br $>$. Acesso em: 20 out. 2010.

GABAS, A. L. et al. Effect of maltodextrin and arabic gum in water vapor sorption thermodynamic properties of vacuum dried pineapple pulp powder. Journal of Food Engineering, v. 82, p. 246-252, 2007 http://dx.doi.org/10.1016/j.jfoodeng.2007.02.029

GABAS, A. L.; MENEGALLI, F. C.; TELIS-ROMERO, J. Thermodynamic models for water sorption by grape skin and pulp. Drying Technology, v. 17, n. 4-5, p. 961-974, 1999.

GABAS, A. L.; MENEGALLI, F. C.; TELIS-ROMERO, J. Water sorption enthalpy-entropy compensation based on isotherms of plum skin and pulp. Journal of Food Science, v. 65, n. 4, p. 680-684, 2000. http://dx.doi.org/10.1111/j.1365-2621.2000.tb16072.x

IGLESIAS, H. A.; CHIRIFE, J. An alternative to the GAB model for the mathematical description of moisture sorption isotherms of foods. Food Research International, v. 28, p. 317-321, 1995. http://dx.doi. org/10.1016/0963-9969(94)00002-P

JOWITT, R. et al. Physical properties methods of foods. London: Applied Science Publishers, 1983. PMid:6881502.

LABUZA, T. P. Sorption phenomena in foods. Food Technology, v. 22, n. 3, p. 263-272, 1968

LABUZA, T. P.; KAANANE, A.; CHEN, J. Y. Effect of temperature on the moisture sorption isotherms and water activity shift of two dehydrates foods. Journal of Food Science, v. 50, p. 385-389, 1985.

MACHADO, K. C.; DAMM, D. D.; FORNARI, C. C. M. J. Reaproveitamento tecnológico de resíduo orgânico: casca de coco verde na produção de gabinetes ecológicos de computadores. In: FÓRUM INTERNACIONAL DE RESÍDUOS SÓLIDOS, 2., 2009, Ilhéus. Anais... Ilhéus, 2009.

MEDINA, J. C. Coco: da cultura ao processamento e comercialização. Campinas: ITAL, 1980. (Frutas Tropicais, n. 5).

MISHRA, V. K.; ORAIKUL, B.; TEMELLI, F. Physical characterization and water sorption of freeze dried dulse Palmaria palmata powder. Journal of Food Processing and Preservation, v. 20, n. 1, p. 25-39, 1996. http://dx.doi.org/10.1111/j.1745-4549.1996. tb00338.x

MOURA, E. G. et al. Produção e qualidade de frutos de coqueiro anã-verde conduzido em sistema silvipastoril e monocultura no leste de Minas Gerais. In: CONGRESSO BRASILEIRO DE FRUTICULTURA, 2008, Vitoria. Anais... Vitoria, 2008.

PARK, K. J.; BIN, A.; BROD, F. P. R. Obtenção das isotermas de sorção e modelagem matemática para a pêra bartlett (Pyrus sp.) com e sem desidratação osmótica. Ciência e Tecnologia de Alimentos, v. 21 , n. 1 , p. $73-77,2001$. http://dx.doi.org/10.1590/S010120612001000100016

RIZVI, S. S. H. Thermodynamic properties of foods in dehydration. In: RAO, M. A.; RIZVI, S. S. H. (Eds.). Engineering properties of foods. 2. ed. New York: Marcel Dekker, 1986. p. 133-214.

RIZVI, S. S. H. Thermodynamic properties of foods in dehydration. In: RAO, M. A.; RIZVI, S. S. H. (Eds.). Engineering properties of foods. 2. ed. New York: Marcel Dekker, 1995. 531 p.

ROSA, M. F.; ABREU, F. A. P. Água de coco: métodos de conservação. Brasília: Embrapa, 2000.

SAMAPUNDO, S. et al. Sorption isotherms and isosteric heats of sorption of whole yellow dent corn. Journal of Food Engineering, v. 79, p. 168-175, 2007. http://dx.doi.org/10.1016/j. jfoodeng.2006.01.040

SENHORAS, E. M. Estratégias de uma agenda para a cadeia agroindustrial do coco: transformando a ameaça dos resíduos em oportunidades eco-eficientes. 2003. Monografia (Graduação)Instituto de Economia, Universidade Estadual de Campinas, Campinas, 2003.

SILVA, G. G. Desenvolvimento e qualidade da água de frutos de coqueiro anão. Areia, 2006.

SILVA, Y. C.; MATA, M. E. R. M. C.; DUARTE, M. E. M. Atividade de água em pó microencapsulado com amido modificado: estudo de dois modelos matemáticos. In: SIMPÓSIO BRASILEIRO DE PÓS COLHEITA DE FRUTOS TROPICAIS, 2005, João Pessoa. Anais... João Pessoa: UFPB, 2005.

SIMAL, S. et al. Water desorption thermodynamic properties of pineapple. Journal of Food Engineering, v. 80, p. 1293-1301, 2007. http://dx.doi.org/10.1016/j.jfoodeng.2006.10.001

STRUMILLO, C.; KUDRA, T. Drying: principles, applications and design. New York: Gordon and Breach Science Publishers. 448 p. 1986.

TELIS, V. R. N. et al. Water sorption thermodynamic properties applied to persimmon skin and pulp. Thermochimica Acta, v. 343, n. 1-2, p. 49-56, 2000.

TIMMERMANN, O.; CHIRIFE, J.; IGLESIAS, H. A. Water sorption isotherms of foods and foodstuffs: BET or GAB parameters? Journal of Food Engineering, v. 48, p. 19-31, 2001. http://dx.doi. org/10.1016/S0260-8774(00)00139-4

TSAMI, E.; MARINOS-KOURIS, D.; MAROULIS, Z. B. 1990. Water sorption isotherms of raisins, currants, figs, prunes and apricots. Journal of Food Science, v. 55, n. 6, p. 1594-1597,1625, 1990.

YOSHIDA, C. M. P. Estudo da cinética de secagem do milho superdoce em leito fixo. In: CONGRESSO BRASILEIRO DE SISTEMAS PARTICULADOS, 1996, Uberlândia. Anais... Uberlândia: Universidade Federal de Uberlândia, 1996. v. 1, p. 307-312.

YOUNG, J. F. Humidity control in the laboratory using salt solutions: a review. Journal of Applied Chemistry, v. 17, n. 9, p. 241-245, 1967. http://dx.doi.org/10.1002/jctb.5010170901 